\title{
Evaluation of freezing injury in temperate fruit trees
}

\author{
Duk Jun $\mathrm{Yu}^{1,2} \cdot$ Hee Jae Lee $\mathrm{e}^{1,2}$
}

Received: 13 April 2020 / Revised: 28 May 2020 / Accepted: 2 June 2020 / Published online: 24 August 2020

(c) The Author(s) 2020

\begin{abstract}
Freezing is a major environmental stress limiting the geographical distribution, growth, and productivity of temperate fruit trees. The extent of freezing injury in the trees depends on the rate at which the temperature decreases, the minimum temperature reached, and the duration of the freezing conditions. The ability to tolerate freezing temperatures under natural conditions varies greatly among fruit tree species, cultivars, and tissues. Freezing injury must be precisely evaluated to reliably predict the winter survival and productivity of the trees in specific regions, to screen for tolerant species and cultivars, and to develop cultural strategies that reduce freezing stress. Various methods are used to evaluate freezing injury in temperate fruit trees under field and artificial conditions, including visual evaluation of tissue discoloration, thermal analysis, determination of electrolyte leakage, and triphenyl tetrazolium chloride reduction analysis. In this review, we describe the most frequently used experimental procedures for evaluating freezing injury.
\end{abstract}

Keywords Dehydration $\cdot$ Electrolyte leakage $\cdot$ Exotherm $\cdot$ Freezing injury $\cdot$ Fruit tree $\cdot$ Tetrazolium

\section{Introduction}

Freezing injury in plants occurs when temperatures drop below the freezing point of water. When plant cells are exposed to subfreezing temperatures, ice first forms in the extracellular spaces that have the highest osmotic potential and the highest levels of ice nucleators and continues to form toward the decreasing water potential (Pearce 2001; Wisniewski et al. 2014). As the temperature decreases, the extracellular ice crystals grow with the withdrawal of liquid water from the unfrozen protoplasts and ultimately the intracellular ice crystals form, which is lethal to the cells (Pearce 2001; Guy 2003; Arora 2018). Freezing injury appears to depend on a common mechanism involving cell dehydration and membrane disintegration via ice formation during freezing (Steponkus 1984; Yamazaki et al. 2009; Moran et al. 2011; Arora 2018).

Communicated by Heakeun Yun, Ph.D.

Hee Jae Lee

heejlee@snu.ac.kr

1 Department of Plant Science, Seoul National University, Seoul 08826, Republic of Korea

2 Research Institute of Agriculture and Life Sciences, Seoul National University, Seoul 08826, Republic of Korea
Freezing is a major environmental stress that limits the geographical distribution, growth, and productivity of temperate fruit trees. Freezing injury in the trees includes winter sunscald of thin-barked species, frost splitting of trunks, blackheart of stems, freezing of roots, midwinter kill of dormant flower buds, death of cambium in twigs, branches, and trunks, and frost damage to flowers and fruit during spring and fall (Weiser 1970; Pearce 2001).

The ability to tolerate freezing temperatures under natural conditions varies greatly among fruit tree species, cultivars, and tissues (Rodrigo 2000; Neuner et al. 2010; Aslamarz et al. 2011; Moran et al. 2011; Lee et al. 2013; Yu et al. 2017). Evaluation of freezing injury is important for predicting winter survival and regrowth the following spring, and productivity of temperate fruit trees in specific regions. Such evaluation is also needed to identify freezing-tolerant species and cultivars and to establish cultural strategies that reduce freezing stress. In this review, we explain how freezing injury can be evaluated in temperate fruit trees and describe the most frequently used experimental procedures to evaluate freezing injury. 


\section{Conditions for evaluating freezing injury}

\subsection{Field conditions}

Freezing injury in temperate fruit trees can be evaluated in the field by determining their survival and regrowth capacity during or following a test winter (Proebsting and Mills 1972; Clore et al. 1974; Layne and Ward 1978; Rajashekar et al. 1982). However, evaluation of freezing injury in the field is complex and often unreliable, because the temperatures of test winters fluctuate, sometimes greatly, from year to year. The winter survival of the trees is also influenced by a variety of factors, including the timing, duration, and rate of temperature decline and rise, the minimum temperature reached, the nucleation temperature, the number of freezethaw cycles, and snow cover (Proebsting and Mills 1972; Guy 2003).

\subsection{Artificial conditions}

Various methods have been employed to evaluate injury in temperate fruit trees under artificial freezing conditions (Steponkus and Lanphear 1967; Ristic and Ashworth 1995; Nesbitt et al. 2002; Neuner et al. 2010; Aslamarz et al. 2011; Moran et al. 2011; Lee et al. 2012, 2013; Pramsohler et al. 2012; Szymajda et al. 2013; Yu et al. 2017). Samples can be subjected to precisely controlled freezing temperatures of various durations and rates of cooling in a growth chamber or bath circulator and then evaluated for freezing injury. Containerized whole trees or tree parts can be tested, with most studies focusing on flower buds and shoots. In this way, large numbers of samples can be handled within a short period of time and reproducible values can be obtained for any given set of controlled freezing conditions. However, the amount of freezing injury can change depending on the rate and duration of the artificial freezing. Furthermore, the values obtained under artificial conditions do not always reflect the true cold hardiness of a species or cultivar, or predict its survival under natural conditions. Nevertheless, such values can be used as valid parameters for predicting the relative amount of freezing injury during winter and the severity of spring frost damage (Barranco et al. 2005; Ehlenfeldt et al. 2006; Imani et al. 2011; Lee et al. 2013; Moghadam et al. 2015).

\section{Methods for evaluating freezing injury}

\subsection{Visual evaluation}

Membrane disruption caused by freezing allows cytosolic enzymes to act on substrates that are normally sequestered (Rouet-Mayer et al. 1990). The injured tissues can discolor as cytosolic enzymes act on phenolic substrates. Polyphenol oxidase is one enzyme known to be responsible for discoloration in mechanically injured tissues (Vámos-Vigyázó 1981; Van Lelyveld and Bower 1984; Lee et al. 2005). Polyphenol oxidase catalyzes the oxidation of phenolic compounds to $o$-quinones, which subsequently polymerize to form darkcolored pigments (Rouet-Mayer et al. 1990). The discoloration of freeze-injured tissues can be evaluated visually under field or artificial freezing conditions (Rodrigo 2000; Ehlenfeldt et al. 2006; Mills et al. 2006; Lenz et al. 2013, 2016; Moghadam et al. 2015).

Artificial freezing experiments usually employ three to five appropriate target freezing temperatures. Freezing and thawing are performed in a growth chamber or bath circulator equipped with a temperature controller, with temperature changes applied at a rate of $2^{\circ} \mathrm{C} / \mathrm{h}$. Flower buds or shoots are kept at the target freezing temperature for 4-6 h. After freezing and thawing, samples are kept at room temperature for some time to allow symptoms to develop. This incubation can last from several days to one week depending on the tissue type and growing season. Samples are cut longitudinally and their injury is evaluated based on discoloration, sometimes with an aid of a digital microscope (Fig. 1).

Percent injury is plotted against freeze temperature to generate a sigmoid curve. The sigmoid curve associated with the temperature at which $50 \%$ injury occurred $\left(\mathrm{LT}_{50}\right)$ is generally used to characterize freezing injury by regression analysis. $\mathrm{LT}_{50}$ values can also be calculated using a linear
Fig. 1 Discoloration of blueberry flower buds caused by various freezing temperatures. The tissues were subjected to various freezing temperatures in a circulating water bath for $2 \mathrm{~h}$ and their discoloration was visually evaluated by using a digital microscope following the incubation at room temperature for $24 \mathrm{~h}$

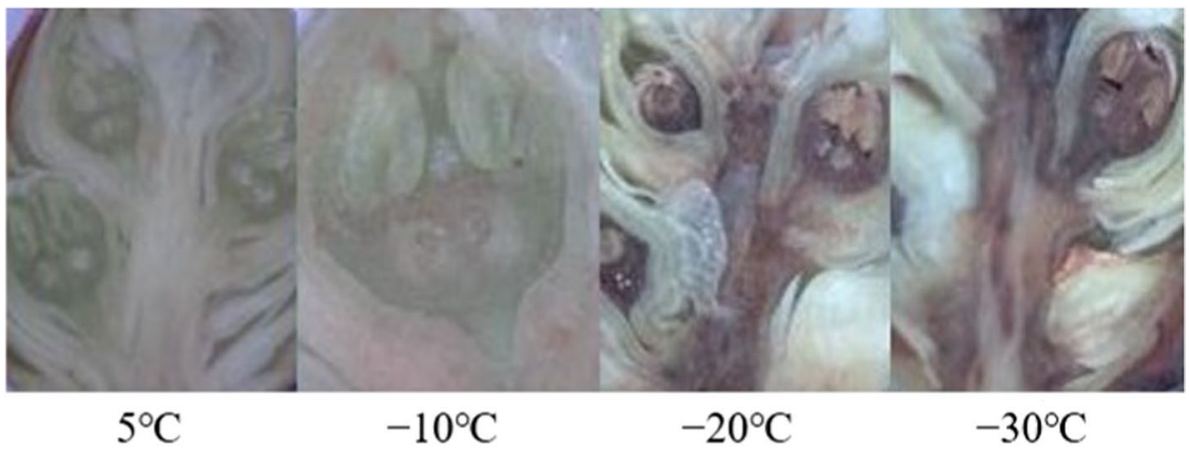


regression model, assuming that the section of the sigmoid curve between 20 and $80 \%$ can be regarded as linear ( $\mathrm{Gu}$ 1999; Szalay et al. 2016).

Visual evaluation requires less instrumentation than other methods and is considered reliable. However, it is qualitative and subjective in nature as well as being more time consuming and requiring larger amounts of sample material than other methods. Nevertheless, visual evaluation has widely been used to determine freezing injury in many temperate fruit trees, including apple (Embree and McRae 1991; Kang et al. 1998; Moran et al. 2011), pear (Kang et al. 1998), peach (Salazar-Gutiérrez et al. 2014; Liu et al. 2019), grape (Jones et al. 1999; Mills et al. 2006), and blueberry (Ehlenfeldt et al. 2006; Kishimoto et al. 2014).

Visual evaluation of tissue discoloration is sometimes combined with observations of regrowth capacity, especially when testing whole trees (Embree and McRae 1991). Callus growth on injured woody stems has also been suggested as a measure of freezing injury (Pellett and Heleba 1998; Nesbitt et al. 2002). Regrowth tests require lengthy incubation under favorable growing conditions and the results may be hampered by dormancy. Nevertheless, normal regrowth of a tree is the ultimate measure of its survival and the most reliable parameter for evaluating freezing injury. Visual evaluation of tissue discoloration and regrowth are often used as controls for more quantitative analyses.

\subsection{Thermal analysis}

When temperatures drop below the freezing point, there are abrupt increases in tissue temperatures due to the latent heat release of fusion during ice formation (Quamme et al. 1972; Burke et al. 1976; Kaya and Köse 2017). These temperature increases are called exotherms. Freezing injury can be monitored based on exotherm appearance as ice forms (Mills et al. 2006; Salazar-Gutiérrez et al. 2016; Kaya and Köse 2017; London and Kovaleski 2017; Liu et al. 2019).

Thermal analysis for detecting exotherms is carried out by embedding a small probe of copper-constantan thermocouple under the bark of a moist woody twig or on the surface of buds (Fig. 2). A second thermocouple is commonly embedded in a dry sample of the tissue as a reference. Tissues are usually cooled to $-40{ }^{\circ} \mathrm{C}$ at a rate of -2 or $-20^{\circ} \mathrm{C} / \mathrm{h}$ in a bath circulator equipped with a temperature controller. Temperatures of the sample tissues are then recorded at $2 \mathrm{~s}$ intervals using a data logger as the surrounding air temperature is steadily lowered.

During thermal analysis, the sample tissues initially cool well below the freezing point of water with no apparent ice formation (Fig. 3). The failure to form ice at temperatures below the freezing point is called supercooling (Burke et al. 1976). At approximately $-5^{\circ} \mathrm{C}$, the first exotherm appears, which represents ice formation in the apoplastic space of xylem tracheary elements and in the intercellular spaces in the cortex, bark, phloem, and so forth (Burke et al. 1976; Neuner et al. 2010). The ice crystals continue to grow, fed by the gradual withdrawal of liquid water from unfrozen protoplasts (Arora 2018). The second exotherm is seen as a shoulder rather than a distinct peak and represents the

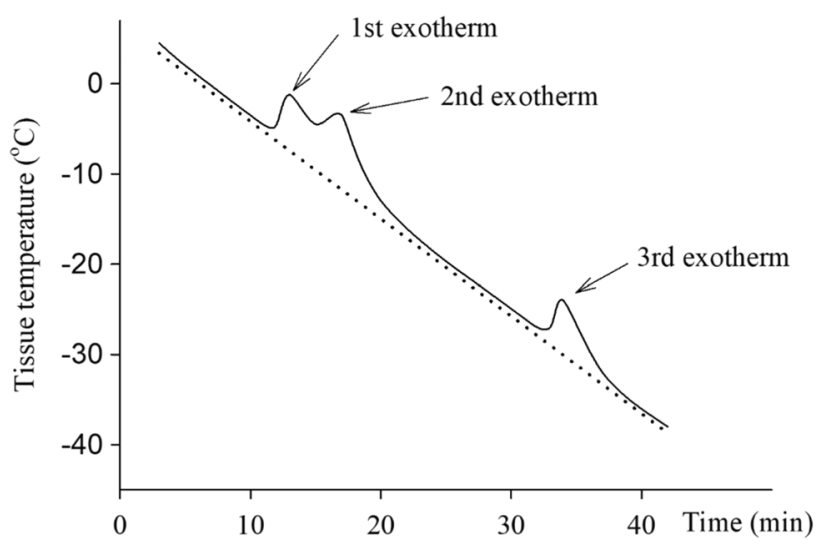

Fig. 3 Changes in tissue temperature during controlled freezing of woody stems. Exotherms are the abrupt tissue temperature increases significantly above ambient due to the latent heat release of fusion during the freezing of water in the excised stem. (modified from Weiser 1970)
Fig. 2 A copper-constantan thermocouple probe embedded in a grapevine bud

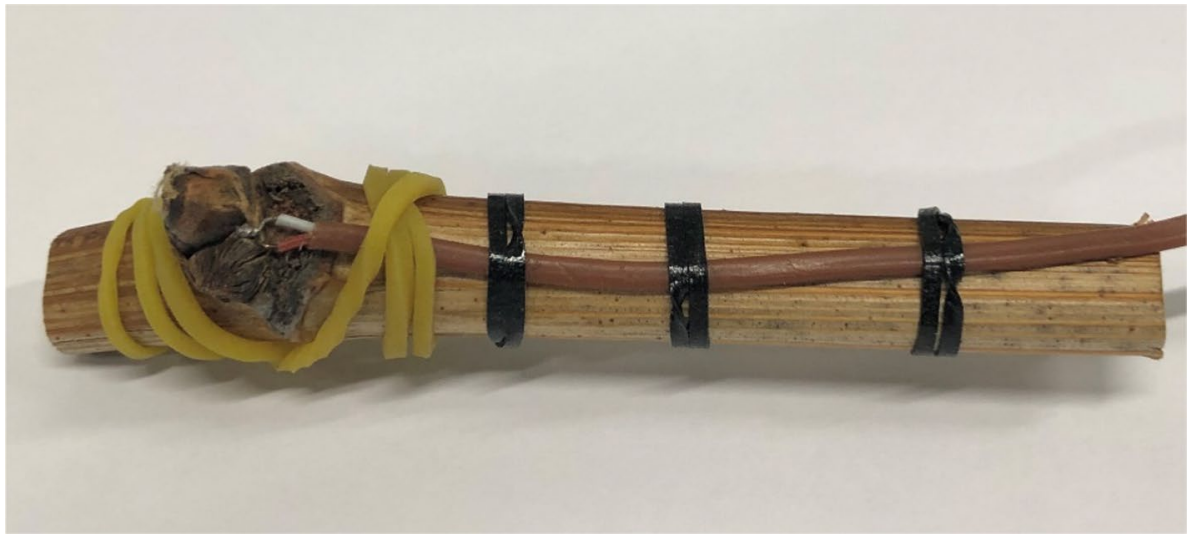


enlargement of extracellular ice crystals. The first and second extracellular exotherms are called high-temperature exotherms. With further cooling, a third, low-temperature exotherm is seen in the thermal analysis curve. The third exotherm represents intracellular ice formation, which is invariably lethal to the cells in which it occurs (George et al. 1974; Mills et al. 2006; Tanino 2012; Charrier et al. 2015; Grant and Dami 2015; Rubio et al. 2016).

The ability to supercool varies among fruit tree species (Quamme 1991), and this species-specific threshold temperature limits their geographical distribution (George et al. 1974; Burke et al. 1976; Wisniewski et al. 2003; London and Kovaleski 2017). In many temperate fruit trees, acclimation to freezing involves the suppression of ice formation at temperatures far below the freezing point (Pramsohler et al. 2012; Salazar-Gutiérrez et al. 2014; Kaya and Köse 2017; Liu et al. 2019). Deep supercooling to as low as $-40{ }^{\circ} \mathrm{C}$ can take place in flower buds and stems, despite ice formation in bud scales and adjacent tissues (George and Burke 1977; Ashworth et al. 1988; Kang et al. 1998). The flower bud primordium is surrounded by an impenetrable cell layer containing waxy deposits in the cell walls (Ashworth 1982; Ashworth et al. 1989). This cell layer isolates the meristematic cells of the primordium from the scales and bud axis and excludes ice crystal penetration. Inside the primordium, there are no strong ice nucleation sites. Thus, as the temperature is lowered, the water in the primordium supercools until the temperature reaches the critical threshold temperature for ice nucleation.

Since low-temperature exotherms are produced by freezing of flower buds and the xylem parenchyma cells in stems (Ashworth et al. 1989; Arora et al. 1992; Volk et al. 2009; Pramsohler et al. 2012), thermal analysis has sometimes been employed to rapidly identify the ability to undergo supercooling during a controlled freezing test in many temperate fruit trees, including apple (Salazar-Gutiérrez et al. 2016), pear (Rajashekar et al. 1982), peach (Ashworth 1982; Ashworth et al. 1989; Kang et al. 1998; Liu et al. 2019), sweet cherry (Salazar-Gutiérrez et al. 2014), grape (Kang et al. 1998; Jones et al. 1999; Mills et al. 2006; Ferguson et al. 2011; Grant and Dami 2015; Rubio et al. 2016; London and Kovaleski 2017; Kaya and Köse 2017), and blueberry (Kishimoto et al. 2014). In some cases, however, the lowtemperature exotherms are undetectable or detected over a wide temperature range, because the xylem parenchyma cells do not freeze simultaneously but rather small groups of the cells appeared to freeze at random points (Neuner et al. 2010; Tanino 2012; Yu et al. 2017).

\subsection{Electrolyte leakage analysis}

Any process that damages the plant membrane will cause the contents of the cell to leak out (Steponkus and Lynch
1989; Duke and Kenyon 1993; Lee et al. 1995; Lee and Cho 1996; Lindén et al. 2000; Nesbitt et al. 2002; Demidchik et al. 2014; Arora 2018). Cellular leakage is a symptom of membrane damage caused by freezing stress (Lindén et al. 2000; Aslamarz et al. 2011; Arora 2018). Leakage can occur without membrane rupture, but is more pronounced when the membrane ruptures and the entire cell contents are released (Duke and Kenyon 1993; Améglio et al. 2005; Yamazaki et al. 2009). Thus, recording the amount of cellular leakage provides an estimate of freezing injury in many temperate fruit trees (Lee et al. 2012, 2013; Moghadam et al. 2015; Yu et al. 2017).

Many different types of cellular contents can be sampled to determine cellular leakage. However, electrolyte leakage is the most frequently measured parameter for evaluating tissue injury, because electrolyte leakage can be determined continuously with an electrical conductivity probe and does not require destructive sampling (Duke and Kenyon 1993; Lindén et al. 2000; Aslamarz et al. 2011; Lee et al. 2012, 2013). Furthermore, electrolyte leakage analysis is simple, rapid, and inexpensive, requires small amounts of sample, and provides quantitative data.

Electrolyte leakage analysis often begins with rinsing the samples with deionized water to remove surface contaminants. Shoot or stem tissues are cut into small pieces and placed into $50-\mathrm{mL}$ conical tubes containing $1 \mathrm{~mL}$ of distilled water. The tubes are incubated in a circulating water bath equipped with a temperature controller. The tubes are cooled at a rate of $2{ }^{\circ} \mathrm{C} / \mathrm{h}$ until the target temperature (as low as $-40^{\circ} \mathrm{C}$ ) is reached, maintained at the target temperature for $2 \mathrm{~h}$, and then thawed at a rate of $2{ }^{\circ} \mathrm{C} / \mathrm{h}$ to $4{ }^{\circ} \mathrm{C}$. The temperatures are monitored with a copper-constantan thermocouple and recorded with a data logger. After the freeze-thaw treatment, the tissues are cut into $1-\mathrm{cm}$ long pieces, then placed in a $15-\mathrm{mL}$ conical tube containing $8 \mathrm{~mL}$ of deionized water, and vacuuminfiltrated for $5 \mathrm{~min}$. The tubes are incubated at room temperature for $20 \mathrm{~h}$ on an orbital shaker at $120 \mathrm{rpm}$. Initial electrical conductivity of the aliquots is measured using an electrical conductivity meter. After autoclaving at $120^{\circ} \mathrm{C}$ for $30 \mathrm{~min}$, followed by incubation at room temperature for $20 \mathrm{~h}$, final electrical conductivity is measured.

The simplest method of expressing the data is to plot the change in electrical conductivity of treated tissue minus the change in electrical conductivity of the control at each temperature, assuming that the differential increase in electrolyte leakage is due to the freezing temperature. Alternatively, the data can be normalized based on percent of total capacity to leak (Lee et al. 2013; Yu et al. 2017). The total capacity to leak can be determined by autoclaving the tissues and measuring the electrical conductivity of the aliquot.

Percent injury is calculated as follows (Arora et al. 1992): 
$\%$ Injury $=\left(\% \mathrm{EL}_{\left(\mathrm{T}^{\circ} \mathrm{C}\right)}-\% \mathrm{EL}_{\left(4{ }^{\circ} \mathrm{C}\right)}\right) /\left(100-\% \mathrm{EL}_{\left(4{ }^{\circ} \mathrm{C}\right)}\right) \times 100$,

where $\% \mathrm{EL}_{\left(\mathrm{T}^{\circ} \mathrm{C}\right)}$ and $\% \mathrm{EL}_{\left(4{ }^{\circ} \mathrm{C}\right)}$ are percent electrolyte leakage (EL) values based on initial electrical conductivity over total electrical conductivity for each freeze target temperature $\left(\mathrm{T}^{\circ} \mathrm{C}\right)$ and unfrozen control $\left(4{ }^{\circ} \mathrm{C}\right)$, respectively. The percent injury data are transformed using the method of Lim et al. (1998), with the percent electrolyte leakage for the $-80{ }^{\circ} \mathrm{C}$-treated sample set at $100 \%$, and adjusted using the following equation (Lee et al. 2013; Yu et al. 2017):

$\%$ Adjusted injury $=\left(\%\right.$ injury $_{\left(\mathrm{T}^{\circ} \mathrm{C}\right)} / \%$ injury $\left._{\left(-80^{\circ} \mathrm{C}\right)}\right) \times 100$

Using the percent-adjusted injury data, quantitative estimates of freezing injury or cold hardiness, that is, $\mathrm{LT}_{50}$ and the temperature at which the rate of injury is maximal $\left(\mathrm{T}_{\max }\right)$, are calculated using the Gompertz function, an asymmetric sigmoid curve appropriate for use in data fitting of a plant's response to temperature stress, as described by Lim et al. (1998) and Lindén et al. (2000).

Electrolyte leakage analysis has been used to evaluate freezing injury in grape canes and buds (Jones et al. 1999), red raspberry canes (Lindén et al. 2000), olive leaves and shoots (Barranco et al. 2005), blueberry shoots (Lee et al. 2012, 2013), and peach trunk bark and wood tissues (Yu et al. 2017). Although electrolyte leakage is not a direct measurement of cellular injury caused by freezing, the values from electrolyte leakage analysis have correlated well with cold hardiness in many temperate fruit trees (Lindén et al. 2000; Nesbitt et al. 2002; Lee et al. 2013; Yu et al. 2017).

\subsection{Triphenyl tetrazolium chloride (TTC) reduction analysis}

TTC (2,3,5-triphenyl-2 H-tetrazolium chloride) is a redox indicator commonly used to measure cellular respiration. In TTC reduction analysis, the colorless TTC is reduced to red 1,3,5-triphenylformazan by the action of various dehydrogenases in living tissues (Lakon 1949). It is sometimes difficult to visually differentiate between living and non-living tissues based on the degree of TTC reduction because of wide variation in the intensity and pattern of the red coloration. Following extraction of the triphenylformazan with an organic solvent, however, the color change can be quantitatively determined spectrophotometrically (Lopez del Egido et al. 2017). Thus, the TTC reduction analysis may be useful for evaluating freezing injury in temperate fruit trees.

For TTC reduction analysis, shoot or stem tissues are subjected to various freezing temperatures as described for the electrolyte leakage analysis. After the freeze-thaw treatment, the samples are placed in $50-\mathrm{mL}$ conical tubes containing $10 \mathrm{~mL}$ of $0.8 \%$ TTC in $0.05 \mathrm{M} \mathrm{K}_{2} \mathrm{HPO}_{4} / \mathrm{KH}_{2} \mathrm{PO}_{4}$ buffer (pH 7.4) and vacuum-infiltrated for 15 min to facilitate absorption of the TTC solution. The tubes are incubated in a growth chamber in darkness at $28^{\circ} \mathrm{C}$ for $20 \mathrm{~h}$, followed by three rinses of the tissues with distilled water. The waterinsoluble triphenylformazan is extracted from each sample with $7 \mathrm{~mL}$ of $95 \%(\mathrm{v} / \mathrm{v})$ ethanol in a water bath at $85{ }^{\circ} \mathrm{C}$ for $10 \mathrm{~min}$. The amount of triphenylformazan, which equals the amount of TTC reduced, is measured at $490 \mathrm{~nm}$ using a spectrophotometer. Percent-adjusted injury data and $\mathrm{LT}_{50}$ values are calculated using the same methods employed for electrolyte leakage analysis.

TTC reduction analysis has been used to evaluate freezing injury in many tree species (Steponkus and Lanphear 1967; Nesbitt et al. 2002; Ruf and Brunner 2003), including walnut (Aslamarz et al. 2011) and peach (Yu et al. 2017). However, its usefulness is limited, since dormant tissues are sometimes erroneously considered to be dead (Busso et al. 2015).

\subsection{Other methods}

Neutral red (3-amino-7-dimethyl-2-methylphenazine hydrochloride), a weak cationic dye, can be used to evaluate freezing injury, since it crosses the membranes of viable cells and accumulates intracellularly (Winckler 1974; Borenfreund and Puerner 1984; Repetto et al. 2008). As cells are injured by freezing, their ability to incorporate neutral red diminishes. Thus, loss of neutral red uptake corresponds to loss of cell viability.

Nuclear magnetic resonance (NMR), a type of spectroscopy which employs radio frequency light, has also been used to assess freezing injury (Burke et al. 1974, 1976). NMR can distinguish between ice crystals and unfrozen water in plant tissues based on their radio frequency spectra (Burke et al. 1974). Since the spectrum becomes progressively broader as freezing progresses, it is possible to measure the amount of unfrozen water in various tissues and thereby estimate freezing injury. Furthermore, localization of unfrozen water and freezing behaviors of various tissues at subzero temperatures can be visualized by using the NMR technology combined with image scanners (Liu et al. 1993; Gamble 1994; Kerr et al. 1997; Price et al. 1997). In the images, unfrozen water appears as a light area.

In addition, infrared thermography has been used to monitor ice nucleation and propagation in a variety of plant species and tissue types (Ceccardi et al. 1995; Wisniewski et al. 1997; Fuller and Wisniewski 1998; Workmaster et al. 1999; Neuner et al. 2010, 2019; Pramsohler et al. 2012). In the infrared thermography using an imaging radiometer or a digital infrared camera, ice formation during freezing is visible as a light area by the latent heat release of fusion as water undergoes phase transition from a liquid to a solid (Ceccardi et al. 1995; Wisniewski et al. 1997; Neuner et al. 2010). 


\section{Conclusion}

To cope with freezing stress, temperate fruit trees have developed various mechanisms regulating ice formation in their tissues during freezing, which results in diverse but species- and tissue-specific freezing patterns. Various methods have been attempted to evaluate freezing injury in the trees under field and artificial conditions. To precisely evaluate the freezing injury, the methods should be chosen based on the species- and tissue-specific freezing patterns. The most frequently used methods are visual evaluation of tissue discoloration, thermal analysis, electrolyte leakage analysis, and TTC reduction analysis. Considering the diverse freezing patterns, freezing injury should not be evaluated based on a single method but rather on at least a couple of methods under both field and artificial conditions. In addition, cumulative data from multi-year evaluations at different phenological stages are needed for more accurate prediction of the survival of fruit trees during winter and their regrowth the following spring. The integrated evaluation of freezing injury will help to ensure successful cultivation of temperate fruit trees.

Acknowledgements This work was carried out with the support of the 'Cooperative Research Program for Agriculture Science and Technology Development (Project No. PJ014925022020)', Rural Development Administration, Republic of Korea.

Authors' contribution DJY planned and wrote the manuscript; HJL supervised and wrote the manuscript.

\section{Compliance with ethical standards}

Conflict of interest The authors declare that they have no conflict of interest.

Open Access This article is licensed under a Creative Commons Attribution 4.0 International License, which permits use, sharing, adaptation, distribution and reproduction in any medium or format, as long as you give appropriate credit to the original author(s) and the source, provide a link to the Creative Commons licence, and indicate if changes were made. The images or other third party material in this article are included in the article's Creative Commons licence, unless indicated otherwise in a credit line to the material. If material is not included in the article's Creative Commons licence and your intended use is not permitted by statutory regulation or exceeds the permitted use, you will need to obtain permission directly from the copyright holder. To view a copy of this licence, visit http://creativecommons.org/licenses/by/4.0/.

\section{References}

Améglio T, Alves G, Decourteix M, Poirier MM, Bonhome M, Guilliot A, Sakr S, Brunel N, Petel G, Rageau R, Cochard H, Julien JLJ, Lacointe A (2005) Winter biology in walnut tree: freezing tolerance by cold acclimation and embolism repair. Acta Hortic 705:241-249. https://doi.org/10.17660/ActaHortic.2005.705.29

Arora R, Wisniewski ME, Scorza R (1992) Cold acclimation in genetically related (sibling) deciduous and evergreen peach (Prunus persica [L.] Batsch). 1. Seasonal changes in cold hardiness and polypeptides of bark and xylem tissues. Plant Physiol 99:1562-1568. https://doi.org/10.1104/pp.99.4.1562

Arora R (2018) Mechanism of freeze-thaw injury and recovery: a cool retrospective and warming up to new ideas. Plant Sci 270:301-313. https://doi.org/10.1016/j.plantsci.2018.03.002

Ashworth EN (1982) Properties of peach flower buds which facilitate supercooling. Plant Physiol 70:1475-1479. https://doi. org/10.1104/pp.70.5.1475

Ashworth EN, Echlin P, Pearce RS, Hayes TL (1988) Ice formation and tissue response in apple twigs. Plant Cell Environ 11:703710. https://doi.org/10.1111/j.1365-3040.1988.tb01153.x

Ashworth EN, David CA, Wisniewski ME (1989) The formation and distribution of ice within dormant and deacclimated peach flowers. Plant Cell Physiol 12:521-528. https://doi. org/10.1111/j.1365-3040.1989.tb02125.x

Aslamarz AA, Vhdati K, Hassani D, Rahemi M, Mohammadi N, Leslie C (2011) Cold hardiness and its relationship with proline content in Persian walnut. Eur J Hortic Sci 76:84-90

Barranco D, Ruiz N, Campo MG (2005) Frost tolerance of eight olive cultivars. HortScience 40:558-560. https://doi.org/10.21273/ HORTSCI.40.3.558

Borenfreund E, Puerner JA (1984) A simple quantitative procedure using monolayer cultures for cytotoxicity assays (HTD/NR90). J Tissue Cult Methods 9:7-9

Burke MJ, Bryant RG, Weiser CJ (1974) Nuclear magnetic resonance of water in cold acclimating red osier dogwood stems. Plant Physiol 54:392-398. https://doi.org/10.1104/pp.54.3.392

Burke MJ, Gusta LV, Quamme HA, Weiser CJ, Li PH (1976) Freezing and injury in plants. Annu Rev Plant Physiol 27:507-528

Busso C, Torres Y, Ithurrart L, Richards JH (2015) The TTC-technique might not appropriately test the physiological stage of plant tissues. Russ J Plant Physiol 62:551-556. https://doi.org/10.1134/ S1021443715040068

Ceccardi TL, Heath RL, Ting IP (1995) Low temperature exotherm measurement using infrared thermography. HortScience 30:140 142. https://doi.org/10.21273/HORTSCI.30.1.140

Charrier G, Ngao J, Saudreau M, Amélglio T (2015) Effects of environmental factors and management practices on microclimate, winter physiology, and frost resistance in trees. Front Plant Sci 6:259. https://doi.org/10.3389/fpls.2015.00259

Clore WJ, Wallace MA, Fay RD (1974) Bud survival of grape varieties at sub-zero temperatures in Washington. Am J Enol Vitic 25:24-29

Demidchik V, Straltsova D, Medvedev SS, Pozhvanov GA, Sokolik A, Yurin V (2014) Stress-induced electrolyte leakage: the role of $\mathrm{K}^{+}$-permeable channels and involvement in programmed cell death and metabolic adjustment. J Exp Bot 65:1259-1270. https ://doi.org/10.1093/jxb/eru004

Duke SO, Kenyon WH (1993) Peroxidizing activity determined by cellular leakage. In: Böger P, Sandmann G (eds) Target assays for modern herbicides and related phytotoxic compounds. Lewis Publishers, Boca Raton, pp 61-66

Ehlenfeldt MK, Ogden EL, Rowland LJ, Vinyard B (2006) Evaluation of midwinter cold hardiness among 25 rabbiteye blueberry cultivars. HortScience 41:579-581. https://doi.org/10.21273/HORTS CI.41.3.579

Embree CG, McRae KB (1991) An exploratory study of reciprocal apple rootstock and scion hardiness with two methods of assessment. HortScience 26:1523-1525. https://doi.org/10.21273/ HORTSCI.26.12.1523 
Ferguson JC, Tarara JM, Mills LJ, Grove GG, Keller M (2011) Dynamic thermal time model of cold hardiness for dormant grapevine buds. Ann Bot 107:389-396. https://doi.org/10.1093/ aob/mcq263

Fuller MP, Wisniewski M (1998) The use of infrared thermal imaging in the study of ice nucleation and freezing of plants. J Therm Biol 23:81-89. https://doi.org/10.1016/S0306-4565(98)00013-8

Gamble GR (1994) Non-invasive determination of freezing effect in blueberry fruit tissue by magnetic resonance imaging. J Food Sci 59:571-573. https://doi.org/10.1111/j.1365-2621.1994.tb05564.x

George MF, Burke MJ, Pellett HM, Johnson AG (1974) Low temperature exotherms and woody plant distribution. HortScience 9:519-522

George MF, Burke MJ (1977) Cold hardiness and deep supercooling in xylem of shagbark hickory. Plant Physiol 59:319-325. https:// doi.org/10.1104/pp.59.2.319

Grant TNL, Dami IE (2015) Physiological and biochemical seasonal changes in Vitis genotypes with contrasting freezing tolerance. Am J Enol Vitic 66:195-203. https://doi.org/10.5344/ajev.2014.14101

Gu S (1999) Lethal temperature coefficient: a new parameter for interpretation of cold hardiness. J Hortic Sci Biotechnol 74:53-59. https://doi.org/10.1080/14620316.1999.11511071

Guy CL (2003) Freezing tolerance of plants: current understanding and selected emerging concepts. Can J Bot 81:1216-1223. https://doi. org/10.1139/B03-130

Imani A, Barzegar K, Piripirevatlou S (2011) Relationship between frost injury and ion leakage as an indicator of cold hardiness in 60 almond selections. Int J Nuts Relat Sci 2:22-26

Jones KS, Paroschy J, Mckersie BD, Bowley SR (1999) Carbohydrate composition and freezing tolerance of canes and buds in Vitis vinifera. J Plant Physiol 155:101-106. https://doi.org/10.1016/ S0176-1617(99)80146-1

Kang SK, Motosugi H, Yonemori K, Sugiura A (1998) Supercooling characteristics of some deciduous fruit trees as related to water movement within the bud. J Hortic Sci Biotechnol 73:165-172. https://doi.org/10.1080/14620316.1998.11510960

Kaya Ö, Köse C (2017) Determination of resistance to low temperatures of winter buds on lateral shoot present in Karaerik (Vitis vinifera L.) grape cultivar. Acta Physiol Plant 39:209. https://doi. org/10.1007/s11738-017-2513-7

Kerr WL, Clark CJ, McCarthy MJ, de Ropp JS (1997) Freezing effects in fruit tissue of kiwifruit observed by magnetic resonance imaging. Sci Hortic 67:169-179. https://doi.org/10.1016/S0304 -4238(97)00006-X

Kishimoto T, Yamazaki H, Saruwatari A, Murakawa H, Sekozawa Y, Kuchitsu K, Price WS, Ishikawa M (2014) High ice nucleation activity located in blueberry stem bark is linked to primary freeze initiation and adaptive freezing behavior of the bark. AoB Plants 6:plu044. https://doi.org/10.1093/aobpla/plu044

Lakon G (1949) The topographical tetrazolium method for determining the germinating capacity of seeds. Plant Physiol 24:389-394. https ://doi.org/10.1104/pp.24.3.389

Layne REC, Ward CM (1978) Rootstock and seasonal influence on carbohydrate levels and cold hardiness of Redhaven peach. J Am Soc Hortic Sci 103:408-413

Lee HJ, Duke MV, Birk J, Yamamoto M, Duke SO (1995) Biochemical and physiological effects of benzheterocycles and related compounds. J Agric Food Chem 43:2722-2727. https://doi. org/10.1021/jf00058a033

Lee HJ, Cho KY (1996) Light-dependent cellular leakage from cucumber cotyledon discs treated with $\delta$-aminolevulinic acid, oxyfluorfen, and rose bengal. J Photosci 3:1-7

Lee HJ, Kim TC, Kim SJ, Park SJ (2005) Bruising injury of persimmon (Diospyros kaki cv. Fuyu) fruits. Sci Hortic 103:179-185. https:// doi.org/10.1016/j.scienta.2004.04.016
Lee JH, Yu DJ, Kim SJ, Choi D, Lee HJ (2012) Intraspecies differences in cold hardiness, carbohydrate content, and $\beta$-amylase gene expression of Vaccinium corymbosum during cold acclimation and deacclimation. Tree Physiol 32:1533-1540. https://doi. org/10.1093/treephys/tps102

Lee JI, Yu DJ, Lee JH, Kim SJ, Lee HJ (2013) Comparison of midwinter cold-hardiness and soluble sugars contents in the shoots of 21 highbush blueberry (Vaccinium corymbosum) cultivars. J Hortic Sci Biotechnol 88:727-734. https://doi.org/10.1080/14620 316.2013.11513031

Lenz A, Hoch G, Vitasse Y, Körner C (2013) European deciduous trees exhibit similar safety margins against damage by spring freeze events along elevational gradients. New Phytol 200:1166-1175. https://doi.org/10.1111/nph.12452

Lenz A, Hoch G, Vitasse Y (2016) Fast acclimation of freezing resistance suggests no influence of winter minimum temperature on the range limit of European beech. Tree Physiol 36:490-501. https:// doi.org/10.1093/treephys/tpv147

Lim CC, Arora R, Townsend EC (1998) Comparing Gompertz and Richards functions to estimate freezing injury in Rhododendron using electrolyte leakage. J Am Soc Hortic Sci 123:246-252. https ://doi.org/10.21273/JASHS.123.2.246

Lindén L, Palonen P, Lindén M (2000) Relating freeze-induced electrolyte leakage measurements to lethal temperature in red raspberry. $\mathrm{J}$ Am Soc Hortic Sci 125:429-435. https://doi.org/10.21273/JASHS .125.4.429

Liu D, Faust M, Millard MM, Line MJ, Stutte GW (1993) Status of water in summer-dormant apple buds determined by magnetic resonance imaging. J Am Soc Hortic Sci 118:632-637. https:// doi.org/10.21273/JASHS.118.5.632

Liu J, Lindstrom OM, Chavez DJ (2019) Differential thermal analysis of 'Elberta' and 'Flavorich' peach flower buds to predict cold hardiness in Georgia. HortScience 54:676-683. https://doi. org/10.21273/HORTSCI13518-18

London JP, Kovaleski AP (2017) Characterization of wild North American grapevine cold hardiness using differential thermal analysis. Am J Enol Vitic 68:203-212. https://doi.org/10.5344/ ajev.2016.16090

Lopez del Egido L, Navarro-Miró D, Martinez-Heredia V, Toorop PE, Iannetta PPM (2017) A spectrophotometric assay for robust viability testing of seed batches using 2,3,5-triphenyl tetrazolium chloride: using Hordeum vulgare L. as a model. Front Plant Sci 8:747. https://doi.org/10.3389/fpls.2017.00747

Mills LJ, Ferguson JC, Keller M (2006) Cold-hardiness evaluation of grapevine buds and cane tissues. Am J Enol Vitic 57:194-200

Moghadam EG, Faramarzi E, Fahadan A, Shabani Z (2015) Screening of freezing tolerance in some dwarf selected mahaleb genotypes. Int J Biosci 6:45-53. https://doi.org/10.12692/ijb/6.3.45-53

Moran RE, Sun Y, Geng F, Zhang D, Fazio G (2011) Cold temperature tolerance of trunk and root tissues in one- and two-year old apple rootstocks. HortScience 46:1460-1464. https://doi.org/10.21273 /HORTSCI.46.11.1460

Nesbitt ML, Ebel RC, Findley D, Wilkins B, Woods F, Himelrick D (2002) Assays to assess freeze injury of satsuma mandarin. HortScience 37:871-877. https://doi.org/10.21273/HORTS CI.37.6.871

Neuner G, Xu B, Hacker J (2010) Velocity and pattern of ice propagation and deep supercooling in woody stems of Castanea sativa, Morus nigra, and Quercus robur measured by IDTA. Tree Physiol 30:1037-1045. https://doi.org/10.1093/treephys/tpq059

Neuner G, Monitzer K, Kaplenig D, Ingruber J (2019) Frost survival mechanism of vegetative buds in temperate trees: deep supercooling and extraorgan freezing vs. ice tolerance. Front Plant Sci 10:537. https://doi.org/10.3389/fpls.2019.00537 
Pearce RS (2001) Plant freezing and damage. Ann Bot 87:417-424. https://doi.org/10.1006/anbo.2000.1352

Pellett NE, Heleba DA (1998) Comparing callus growth with discoloration and electrical conductivity as measures of stem injury after freezing woody plants. J Am Soc Hortic Sci 123:826-831. https ://doi.org/10.21273/JASHS.123.5.826

Pramsohler M, Hacker J, Neuner G (2012) Freezing pattern and frost killing temperature of apple (Malus domestica) wood under controlled conditions and in nature. Tree Physiol 32:819-828. https ://doi.org/10.1093/treephys/tps046

Price WS, Hiroyuki I, Arata Y, Ishikawa M (1997) Visualization of freezing behaviors in flower bud tissues of cold-hardy Rhododendron japonicum by nuclear magnetic resonance microimaging. Aust J Plant Physiol 24:599-605. https://doi.org/10.1071/PP97049

Proebsting EL, Mills HH (1972) A comparison of hardiness responses in fruit buds of Bing cherry and Elberta peach. J Am Soc Hortic Sci 97:802-806

Quamme HA, Stushnoff C, Weiser CJ (1972) The relationship of exotherms to cold injury in apple stem tissues. J Am Soc Hortic Sci 97:608-613

Quamme HA (1991) Application of thermal analysis to breeding fruit crops for increased cold hardiness. HortScience 26:513-517. https ://doi.org/10.21273/HORTSCI.26.5.513

Rajashekar CB, Westwood MN, Burke MJ (1982) Deep supercooling and cold hardiness in genus Pyrus. J Am Soc Hortic Sci 107:968-972

Repetto G, del Peso A, Zurita JL (2008) Neutral red uptake assay for the estimation of cell viability/cytotoxicity. Nat Protocols 3:11251131. https://doi.org/10.1038/nprot.2008.75

Ristic Z, Ashworth EN (1995) Response of xylem ray parenchyma cells of supercooling wood tissues to freezing stress: microscopic study. Int J Plant Sci 156:784-792. https://doi.org/10.1086/297302

Rodrigo J (2000) Spring frosts in deciduous fruit trees: morphological damage and flower hardiness. Sci Hortic 85:155-173. https://doi. org/10.1016/S0304-4238(99)00150-8

Rouet-Mayer MA, Ralambosoa J, Philippon J (1990) Roles of $o$-quinones and their polymers in the enzymic browning of apples. Phytochemistry 29:435-440. https://doi.org/10.1016/00319422(90)85092-T

Rubio S, Dantas D, Bressan-Smith R, Pérez FJ (2016) Relationship between endodormancy and cold hardiness in grapevine buds. J Plant Growth Regul 35:266-275. https://doi.org/10.1007/s0034 4-015-9531-8

Ruf M, Brunner I (2003) Vitality of tree fine roots: reevaluation of the tetrazolium test. Tree Physiol 23:257-263. https://doi. org/10.1093/treephys/23.4.257

Salazar-Gutiérrez MR, Chaves B, Anothai J, Whiting M, Hoogenboom G (2014) Variation in cold hardiness of sweet cherry flower buds through different phenological stages. Sci Hortic 172:161-167. https://doi.org/10.1016/j.scienta.2014.04.002

Salazar-Gutiérrez MR, Chaves B, Hoogenboom G (2016) Freezing tolerance of apple flower buds. Sci Hortic 198:344-351. https:// doi.org/10.1016/j.scienta.2015.12.003

Steponkus PL, Lanphear FO (1967) Refinement of the triphenyl tetrazolium chloride method of determining cold injury. Plant Physiol 42:1423-1426. https://doi.org/10.1104/pp.42.10.1423
Steponkus PL (1984) Role of the plasma membrane in freezing injury and cold acclimation. Annu Rev Plant Physiol 35:543-584. https ://doi.org/10.1146/annurev.pp.35.060184.002551

Steponkus PL, Lynch DV (1989) Freeze/thaw-induced destabilization of the plasma membrane and the effects of cold acclimation. $\mathrm{J}$ Bioenergy Biomembr 21:21-41

Szalay L, Ladányi M, Hajnal V, Pedryc A, Tóth M (2016) Changing of the flower bud frost hardiness in three Hungarian apricot cultivars. Hortic Sci 43:134-141. https://doi.org/10.17221/161/2015HORTSCI

Szymajda M, Pruski K, Zurawicz E, Sitarek M (2013) Freezing injuries to flower buds and their influence on yield of apricot (Prunus armeniaca L.) and peach (Prunus persica L.). Can J Plant Sci 93:191-198. https://doi.org/10.4141/CJPS2012-238

Tanino K (2012) From lab to nature: assessing injury in xylem parenchyma cells. Tree Physiol 32:815-818. https://doi.org/10.1093/ treephys/tps061

Vámos-Vigyázó L (1981) Polyphenol oxidase and peroxidase in fruits and vegetables. Crit Rev Food Sci Nutr 15:49-127. https://doi. org/10.1080/10408398109527312

Van Lelyveld LJ, Bower JP (1984) Enzyme reactions leading to avocado fruit mesocarp discoloration. J Hortic Sci 59:257-263. https ://doi.org/10.1080/00221589.1984.11515195

Volk GM, Waddell J, Towill L, Grauke LJ (2009) Variation in lowtemperature exotherms of pecan cultivar dormant twigs. HortScience 44:317-321. https://doi.org/10.21273/HORTSCI.44.2.317

Weiser CJ (1970) Cold resistance and acclimation in woody plants: a review. HortScience 5:403-408

Winckler J (1974) Vital staining of lysosomes and other cell organelles of the rat with neutral red. Prog Histochem Cytochem 6:1-89

Wisniewski M, Lindow SE, Ashworth EN (1997) Observation of ice nucleation and propagation in plants using infrared video thermography. Plant Physiol 113:327-334. https://doi.org/10.1104/ pp.113.2.327

Wisniewski M, Bassett C, Gusta L (2003) An overview of cold hardiness in woody plants: seeing the forest through the trees. HortScience 38:952-959. https://doi.org/10.21273/HORTSCI.38.5.952

Wisniewski M, Gusta L, Neuner G (2014) Adaptive mechanisms of freeze avoidance in plants: a brief update. Environ Exp Bot 99:133-140. https://doi.org/10.1016/j.envexpbot.2013.11.011

Workmaster BAA, Palta JP, Wisniewski M (1999) Ice nucleation and propagation in cranberry uprights and fruit using infrared video thermography. J Am Soc Hortic Sci 124:619-625. https://doi. org/10.21273/JASHS.124.6.619

Yamazaki T, Kawamura Y, Uemura M (2009) Extracellular freezinginduced mechanical stress and surface area regulation on the plasma membrane in cold-acclimated plant cells. Plant Signal Behav 4:231-233. https://doi.org/10.4161/psb.4.3.7911

Yu DJ, Hwang JY, Chung SW, Oh HD, Yun SK, Lee HJ (2017) Changes in cold hardiness and carbohydrate content in peach (Prunus persica) trunk bark and wood tissues during cold acclimation and deacclimation. Sci Hortic 219:45-52. https://doi. org/10.1016/j.scienta.2017.02.038 